University of Nebraska - Lincoln

DigitalCommons@University of Nebraska - Lincoln

U.S. Environmental Protection Agency Papers

U.S. Environmental Protection Agency

2009

Eloquence De Rigueur for California Deserts

Robert A. Leidy

U.S. Environmental Protection Agency, leidy.robert@epa.gov

Follow this and additional works at: https://digitalcommons.unl.edu/usepapapers

Leidy, Robert A., "Eloquence De Rigueur for California Deserts" (2009). U.S. Environmental Protection Agency Papers. 144.

https://digitalcommons.unl.edu/usepapapers/144

This Article is brought to you for free and open access by the U.S. Environmental Protection Agency at DigitalCommons@University of Nebraska - Lincoln. It has been accepted for inclusion in U.S. Environmental Protection Agency Papers by an authorized administrator of DigitalCommons@University of Nebraska - Lincoln. 


\section{Eloquence De Rigueur for California Deserts}

The California Deserts: an Ecological Rediscovery. Pavlik, B. M. 2008. University of California Press, Berkeley, CA. 365 pp. $\$ 27.50$ (paperback). ISBN 978-0-520-25145-8.

California's deserts are characterized by meager rainfall and, consequently, scattered sources of permanent surface water, extreme seasonal and diurnal fluctuations in temperature, diverse landforms, tortured geologic complexity, and myriad biogeochemical interactions. Together these factors support an often unappreciated, yet astonishingly singular and productive, biota. Environmental gradients in deserts are at once subtle and complex, or what author Bruce Pavlik in The California Deserts: an Ecological Rediscovery artfully terms a "conspiracy of extremes." There have been numerous books written on the natural history of the Earth's various bioregions, including deserts; however, it is rare that such works have successfully woven ecological and cultural elements together to produce provocative and compelling scientific prose. Pavlik has skillfully accomplished this task by creating an eloquent and timely account of an underappreciated and threatened California ecosystem.

Pavlik's book is organized into seven major sections. The first section, "Introduction: The Lost Basket," ingeniously integrates past and present human relationships, beginning with a fictitious, albeit equiprobable, story of a 19th century female Indian's loss of a basket while collecting grass seeds. The lost basket becomes a bridge between past and present following its discovery by "real" botanists a century later.
The relationship of past and present within the context of human culture and the natural environment is a persistent theme throughout the book. Pavlik's consistent ability to blend seamlessly cultural and ecological themes is impressive.

California's deserts are perhaps most fittingly described as a vast and borderless land. In the second section, "Rediscovery," Pavlik eloquently characterizes the California desert's original inhabitants: "Indians lived within deserts, were born, fed, and raised on them, suffered the extremes and uncertainties, and passed into the ancient, strong soils" (p. 17). In arrant contrast, the modern human experience is one of rediscovery, as an outsider, rather than one that is anchored within the ecological context of the landscape. The reader experiences the California deserts through the eyes of explorers, missionaries, immigrants, scientists, and artists. The chapter is agreeably ordered into several major themes that capture the discordant motives of those coming to the desert to explore, conquer, understand, or cherish, but always as an incomer or interloper.

In the book's third section, Pavlik skillfully describes California's three deserts, the Great Basin, Mohave, and Sonoran, as a conspiracy of extremes. As such, each desert may be distinguished by characteristic attributes of geography, climate, soils, and surface and ground water. The section is characterized by liberal displays of tables, figures, and photographs illustrating important concepts. I found the comparisons in Table 1 ("Abiotic Characteristics of California Deserts") among each desert's abiotic characteristics particularly interesting. For example, across this bioregion there is great environmental variation in elevation ( -280 feet mean sea level to $+14,246$ feet), mean rainfall ( 2 to 16 inches), temperature extremes ( $\leq 32$ to $121^{\circ} \mathrm{F}$ ), and evapotranspiration-toprecipitation ratio (1:7 to $2: 32$ ). Although emphasizing that each desert has singular, defining traits, Pavlik also successfully stitches each into the larger fabric that is the desert bioregion, stressing commonalties perhaps best evidenced in the subtle and often seamless ecological boundaries where they meet.

Writing about ecosystem processes and functions in an engrossing yet instructive style and tone is an arduous challenge. That is why I consider the forth section, "Operations and Origins," a masterpiece of scientific prose. Pavlik successfully "sets the table" for the sections that follow by presenting such knotty topics as photosynthesis, resource limitation, primary productivity, energy flow, nutrient cycling, succession, ecological models, and desert ecosystem origins by employing effective, persuasive, and factual prose. The artwork is elucidative and expertly rendered, crystallizing key concepts.

The fifth section, "Remarkable Biota," is perhaps the most fascinating. Pavlik describes the rich biodiversity of the California desert bioregion, documented at about 2500 native plant and vertebrate animal species, through the overarching organizational context of how organisms have evolved to persist in an environment characterized by extreme drought. Pavlik's knowledge of the ecology of various plant and 
animal taxa is impressive. Organisms are grouped into drought-susceptible (e.g., phreatophytic trees such as California fan palm [Washingtonia filifera], dragonflies), droughtavoiding (i.e., desert herbs, droughtdeciduous scrubs, desert tortoise [Gopherus agassizii]), and droughttolerant (i.e., desert mosses, stemsucculent cacti, desert kangaroo rat [Dipodomys deserti]) species. Perhaps there is no more salient illustration of the California desert's remarkable biota than its fishes and the aquatic environments in which they persist. Fishes are droughtsusceptible species; each species depends on geographically isolated, small, permanent water bodies to persist. Pavlik uses desert pupfishes (Cyprinodon spp.) to illustrate the evolution of physiological tolerances to an array of extreme environmental conditions, including those related to temperature, salinity, and food resources.

Billions of algae-feeding koo-chahbee, the Mono Lake alkali flies (Ephydra bians), and the endemic Mono brine shrimp (Artemia monica) are essential parts of the Great Basin's Mono Lake food web, supporting many animals including, historically, humans. In "Greater than the Sum of the Parts," Pavlik describes desert species and their communities as interwoven like the twine of a living basket. A particular strength of Pavlik's writing is his ability to stitch together a seamless and eloquent overview of the markedly distinct community types comprising California's three deserts, while at the same time emphasizing their similarities and the subtle ecological transitions from one community to another that bring these communities together to form a bioregion. His examples and graphics are excellent and informative.

In 1962 my father returned home from Marine Corps military exercises at Twenty-nine Palms in California's
Sonoran Desert with a desert tortoise pulled from the path of a tank. It became my pet, and I unwittingly a part of the long legacy of exploitation of California's deserts. My family also spent time during the early 1960s at my great aunt's 5-acre desert homestead east of the town of Mohave. The genesis of her small plot was the Homestead Act of 1862. With the alien-like silhouettes of native Joshua trees (Yucca brevifolia) as witnesses, my brother and I would help my aunt irrigate a true invader, the Italian cypress (Cupressus sempervirens), in the hopes of providing meager shade for her cinderblock house. The water we used was transported in jugs from her home in Los Angeles some 120 miles away across bumpy, bulldozed roads to her desert homestead. The water we used originated within the Owens or Colorado river valleys having been transported hundreds of miles in pipelines and canals to Los Angeles, only to be bottled and driven in her car to the Mohave Desert. Little did I understand then that my family's relationship with the desert was a destructive one, contributing to the ecological degradation of a place we seemingly cherished.

In this vein, Pavlik's final section, "The Future of This Arid Bioregion," is a sobering, if somewhat depressing, account of current and future threats to California deserts. Pavlik addresses the loss of isolation through human incursion, habitat fragmentation, introduction of nonnative species, water depletion, air pollution, and livestock grazing. Because of changes brought about by modern humans, 19\% (480 species) of the bioregion's vascular plants and vertebrates are listed as of conservation concern. Many of the threats are likely intractable. For example, the introduction and rapid spread of cheatgrass (Bromus tectorum) in the late 19th century has changed soil-water relationships throughout much of the California Desert Bioregion, resulting in the loss of native perennial grasses and an increased frequency and intensity of wildfires.

The section ends with an overview of potential ecological remedies for the plight of California deserts. A resource-centered management approach is recommended, with a particular emphasis on the implementation of restoration strategies. I found this section of the book a little "bare bones" relative to the other sections, but this may be due in large part to my desire to have Pavlik save the remnants of what he has beautifully described in the remainder of the book.

An overarching strength of the book throughout is the artwork. It contains a generous, diverse, and stunning array of color and black and white photographs. The figures and tables are expertly rendered and composed, and are consistently compelling in their presentation of concepts and information. The references are very useful and are a great source of additional information. The index is well organized and contains a broad range of subject headings. Finally, the book is printed on highquality paper.

Through the eloquent and skillful interweaving of cultural, scientific, and natural history themes, Pavlik and University of California Press have set a new standard for books on the ecology of natural bioregions. I strongly recommend the book for all students, researchers, and amateur naturalists interested in the California deserts. Beyond its obvious academic value, the book is artistically beautiful, and therefore I also highly recommended it for anyone interested in deserts or the natural world.

\section{Robert A. Leidy}

U.S. Environmental Protection Agency, 75 Hawthorne Street, San Francisco, CA 94105, U.S.A., email leidy.robert@epa.gov 